\title{
ROLES OF METABOLIC LEVEL AND TEMPERATURE REGULATION IN THE ADJUSTMENT OF WESTERN PLUMED PIGEONS (LOPHOPHAPS FERRUGINEA) TO DESERT CONDITIONS
}

\author{
WILLIAM R. DAWSON and ALBERT F. BENNETT*
}

Department of Zoology, The University of Michigan, Ann Arbor, Michigan 48104; and Department of Zoology, University of Western Australia, Nedlands, W.A. 6009, Australia

(Received 13 May 1972)

\begin{abstract}
Standard metabolic rate of western plumed pigeons (Lophophaps ferruginea) averages $0.88 \mathrm{ml} \mathrm{O}_{2}(\mathrm{~g} \mathrm{hr})^{-1}$ during summer. This rate and the rate of evaporative water loss by these birds at $25^{\circ} \mathrm{C}$ are well below levels anticipated for birds of comparable size $(81 \mathrm{~g})$.

2. Summer and late fall birds did not have significantly different minimal thermal conductances, the means for both approximating $1.8 \mathrm{kcal}\left(\mathrm{m}^{2} \mathrm{hr}{ }^{\circ} \mathrm{C}\right)^{-1}$.

3. A relatively low level of metabolism and effortless evaporative cooling restrict the caloric burden for western plumed pigeons in the hot and arid regions of northwestern Australia where these birds live. Other pigeons closely associated with hot and arid environments also have relatively low metabolic rates.
\end{abstract}

\section{INTRODUCTION}

THE AVIAN family Columbidae (pigeons and doves) is an excellent source of material for ecophysiological studies, for it is represented through its numerous species from equatorial to high temperate latitudes, from low to high elevations and from xeric to mesic habitats. Investigations of the temperature regulation and water metabolism of several representatives of this group inhabiting the hot deserts of North America have been reported (Bartholomew \& Dawson, 1954; Bartholomew \& MacMillen, 1960; Hudson \& Brush, 1964; Smyth \& Bartholomew, 1966; Lasiewski et al., 1966a, b; MacMillen \& Trost, 1966, 1967a, b; Willoughby, 1966; Bartholomew et al., 1968). These investigations have contributed to understanding of the physiological and behavioral mechanisms allowing these birds to contend successfully with their harsh environment. They have been complemented by work such as that of Scothorne (1959), Calder \& Schmidt-Nielsen (1966, 1967, 1968), SchmidtNielsen et al. (1970) and Crawford \& Kampe (1971) on ion metabolism, respiration and thermoregulation of the domestic pigeon (Columba livia), and of McFarland \& Wright (1969) on water conservation of the ringdove (Streptopelia risoria).

* Present address : Department of Zoology, University of California, Berkeley, California 94720, U.S.A. 
While the information now available on the responses of pigeons and doves to heat and aridity is extensive, it is scarcely comprehensive. This fact and the severe climate in which the western plumed pigeon (Lophophaps ferruginea) occurs prompted us to undertake a study of some physiological responses of this bird to temperature. This partridge-like species is confined to the hot and arid portions of northwestern Australia, occurring from the Pilbara District south to the Gascoyne River and inland to Meekatharra, Western Australia (Serventy \& Whittell, 1962) and also in the West Kimberley District of that state (Goodwin, 1967). It frequents rocky ground near water (Gould, 1865), and appears to drink regularly. The most conspicuous plant in its environment is spinifex grass (Triodia). We felt that study of this Australian species would be particularly useful in the initiation of physiological comparisons among xerophilous representatives of the family Columbidae from the Eastern and Western Hemispheres, birds that presumably have arrived at their adjustments to heat and aridity quite independently.

\section{MATERIALS AND METHODS}

The sixteen birds used in our study were trapped on Hooley Station $\left(21^{\circ} 40^{\prime} \mathrm{S}, 118^{\circ} 00^{\prime} \mathrm{E}\right)$ near Wittenoom, Western Australia in February 1970. In the 15 days preceding air shipment to the University of Western Australia, Nedlands, these animals had been contending with warm to hot temperature conditions. The maximum and minimum temperatures recorded for the Wittenoom area in this period were 43.0 and $19.4^{\circ} \mathrm{C}$, respectively. The average maximum and minimum temperatures for February 1970 , were 38.3 and $25.2^{\circ} \mathrm{C}$, respectively. After arrival at the University, the birds were maintained in outdoor flight cages where they were subjected to a cooler regimen; the mean maximum and minimum temperatures for this area are as follows: 29.4 and $17.5^{\circ} \mathrm{C}$ (February), 27.4 and $16.4^{\circ} \mathrm{C}$ (March), 24.6 and $14 \cdot 1^{\circ} \mathrm{C}$ (April) and 20.6 and $11.6^{\circ} \mathrm{C}$ (May). Water and food were available ad lib., except during experiments. The food consisted of milo maize, canary seed and millet. Lettuce was provided weekly. The birds fared well on this diet. Their weights averaged $80.7 \pm 6.1$ (S.D.) g during Feb. and Mar. and $83.8 \pm 6.2$ in May, the two periods in which physiological measurements were conducted.

Rates of oxygen consumption and evaporative water loss were measured simultaneously between 2200 and $2300 \mathrm{hr}$ on birds that had been resting in darkened metabolism chambers for 6-7 hr and had been away from food for 8-9 hr, a sufficient period for them to become postabsorptive. Each chamber, which was fashioned from a new 2-gal (Imperial) paint can, comprised a part of an open-circuit metabolism system similar to that described by Dawson W. R. \& Fisher (1969). Temperature within these chambers was maintained within $0 \cdot 2^{\circ} \mathrm{C}$ of the desired level by keeping them in a thermostatically controlled cabinet that could be set at any desired level between 5 and $50^{\circ} \mathrm{C}$. The chambers were shielded from both the heating and cooling elements within this cabinet, which was fitted with a fan for air circulation. The chamber temperatures $\left(T_{a}\right)$ were measured with copper-constantan thermocouples used in conjunction with a recently calibrated Honeywell multipoint recording potentiometer.

In experiments conducted below $40^{\circ} \mathrm{C}, T_{\mathrm{a}}$ was maintained at the test level throughout the period over which the birds were confined to the metabolism chambers. A different procedure was followed in experiments involving higher temperatures, to avoid excessive dehydration of these animals. The chambers were maintained at $25^{\circ} \mathrm{C}$ for the first $3 \mathrm{hr}$, the temperature then being increased to the test level over the fourth hour. Metabolic measurements were made during the sixth hour, after the animals had been exposed to the desired $T_{\mathrm{a}}$ for at least $60 \mathrm{~min}$. 
True rates of oxygen consumption $\left(\dot{V}_{\mathrm{O}_{2}}\right)$ were computed from measurements of the fractional concentrations of this gas in dry, $\mathrm{CO}_{2}$-free air entering and leaving the metabolism chamber housing the animal, and of the rate of air flow (corrected to STPD) through the open-circuit system. A Beckman paramagnetic oxygen analyzer (Model F-3, range 20-21\% $\mathrm{O}_{2}$ ) used in conjunction with a Honeywell recording potentiometer measured the fractional concentrations of $\mathrm{O}_{2}$. Flow rates were determined with Brooks "Sho-rate 150" rotameters. The airstream was dried and rendered $\mathrm{CO}_{2}$ free by passing it through absorbent trains containing silica gel, Drierite (anhydrous $\mathrm{CaSO}_{*}$ ) and Ascarite. The equation of DePocas \& Hart (1957) for upstream flow measurement and $\mathrm{CO}_{2}$-free air was used in the calculation of $\dot{V}_{\mathrm{O}_{3}}$.

Rates of evaporative water loss $\left(\dot{m}_{\text {we }}\right)$ were measured by the gravimetric method described by Dawson W. R. \& Fisher (1969). A Mettler balance accurate to $0 \cdot 3 \mathrm{mg}$ was used to determine changes in the weight of the Drierite tubes used to collect water vapor from the airstream. Tests established that these tubes recovered all but a small fraction of 1 per cent of known amounts of water vapor introduced into the open-circuit system at rates of air flow employed in actual tests of western plumed pigeons. These rates ranged from approximately $330 \mathrm{ml} / \mathrm{min}$ at cool and moderate $T_{\mathrm{a}}$ 's to $3300 \mathrm{ml} / \mathrm{min}$ at the highest temperatures tested, and were held constant in the individual experiments. The actual flow rates employed at the various $T_{\mathrm{a}}$ 's served to maintain the following pressures of water vapor in the metabolism chambers during experiments: $>45^{\circ} \mathrm{C}, 7 \mathrm{~mm} \mathrm{Hg} ; 40 \cdot 1-45^{\circ} \mathrm{C}, 5-8 \mathrm{~mm} \mathrm{Hg} ; 35 \cdot 1-40^{\circ} \mathrm{C}$, $5-10 \mathrm{~mm} \mathrm{Hg} ; 30 \cdot 1-35^{\circ} \mathrm{C}, 3-9 \mathrm{~mm} \mathrm{Hg} ; 25 \cdot 1-30^{\circ} \mathrm{C}, 3-8 \mathrm{~mm} \mathrm{Hg} ; 20 \cdot 1-25^{\circ} \mathrm{C}, 5-9 \mathrm{~mm} \mathrm{Hg}$; $15 \cdot 1-20^{\circ} \mathrm{C}, 4-10 \mathrm{~mm} \mathrm{Hg} ; 10 \cdot 1-15^{\circ} \mathrm{C}, 3-6 \mathrm{~mm} \mathrm{Hg} ;<10^{\circ} \mathrm{C}, 4-6 \mathrm{~mm} \mathrm{Hg}$. These vapor pressures were calculated using the equation of Lasiewski et al. (1966a).

Body temperatures $\left(T_{\mathrm{b}}\right)$ were determined at the end of metabolic tests with a Schultheis thermometer. This device was inserted into the rectum to a sufficient depth $(2 \mathrm{~cm})$ so that a slight withdrawal produced no drop in the indicated temperature.

Frequency of gular flutter by western plumed pigeons was determined in a separate set of tests. An experimental subject was fitted with a rectal thermocouple, the duplex leads (30 gauge) of which were held in place by sewing them to the tail feathers. After the thermocouple was in place, the bird was introduced into a small cylindrical cage of $\frac{1}{2}$-in. wire mesh that was sufficiently confining to prevent kinking or twisting of the thermocouple leads. As soon as these leads were connected to a suitably calibrated Honeywell recording potentiometer, the cage containing the bird was placed inside a thermostatically controlled drying cabinet. Ambient temperature within this cabinet was monitored with a shielded thermistor used in conjunction with a Telethermometer (Yellow Springs Instruments). In one test, this temperature had stabilized at $47^{\circ} \mathrm{C}$ when the bird was introduced. In the four other tests, the $T_{\mathrm{a}}$ was initially lower $\left(25\right.$ or $\left.38^{\circ} \mathrm{C}\right)$ and heating was only commenced after $T_{\mathrm{b}}$ had reached a stable low level. Frequency of gular flutter was measured with a Strobotac Type 1531-A electronic stroboscope (General Radio Co.) calibrated for use with $50 \mathrm{~Hz}$ current. To perform such measurements, the room containing the drying cabinet was darkened, the outer door of this cabinet opened and the stroboscopic observation made through the glass inner door.

\section{Body temperature}

\section{RESULTS}

Body temperatures of western plumed pigeons generally fell between 38 and $40^{\circ} \mathrm{C}$ at the conclusion of metabolic experiments conducted below $30^{\circ} \mathrm{C}$ (Fig. 1) and were not significantly correlated with $T_{\mathrm{a}}$ in either Feb.-Mar. or May birds. The mean body temperatures for birds tested at $T_{a}$ 's below $30^{\circ} \mathrm{C}$ were $39 \cdot 0 \pm 0 \cdot 6$ (S.D.) ${ }^{\circ} \mathrm{C}$ (Feb.-Mar.) and $39.1 \pm 0.5^{\circ} \mathrm{C}$ (May). These means do not differ significantly. 


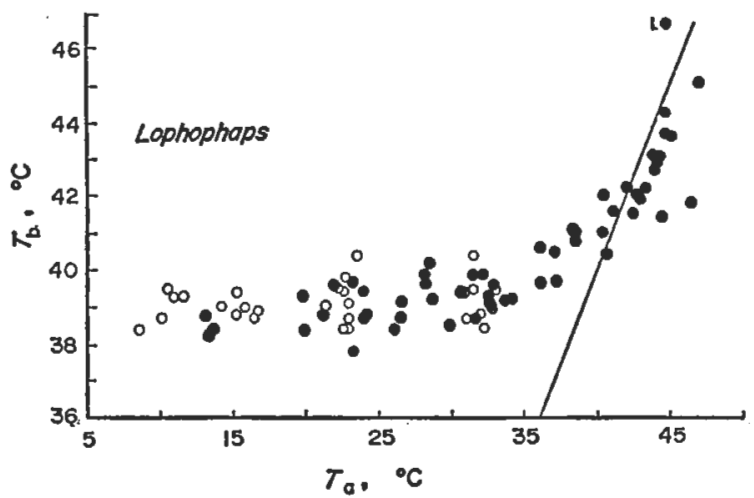

Fig. 1. Relation of body temperature $\left(T_{\mathrm{b}}\right)$ at conclusion of metabolic tests to ambient temperature $\left(T_{\mathrm{a}}\right)$ in western plumed pigeons. Shaded circles: Feb.-Mar. (austral summer) determinations. Unshaded circles: May (austral fall) determinations.

Extensive data on $T_{\mathrm{b}}$ were obtained at $T_{\mathrm{a}}$ 's above $30^{\circ} \mathrm{C}$ only for Feb.-Mar. birds. From this temperature to $47 \cdot 0^{\circ} \mathrm{C}$, the highest level at which metabolic tests were conducted, $T_{\mathrm{b}}$ 's of these animals varied directly with $T_{\mathrm{a}}$ (Fig. 1). This dependence is such that their temperatures increased from approximately 39 to $41^{\circ} \mathrm{C}$ over the zone of thermal neutrality, which extends from 33 to $39^{\circ} \mathrm{C}$ (see below). Western plumed pigeons used in metabolic tests conducted between 42 and $47^{\circ} \mathrm{C}$ generally were $0.5-3.0^{\circ} \mathrm{C}$ cooler than their surroundings at the end of $2-\mathrm{hr}$ exposures to these temperatures. However, one bird tested at $44 \cdot 6^{\circ} \mathrm{C}$ was restless and became overheated, dying at a $T_{\mathrm{b}}$ of $46 \cdot 7^{\circ} \mathrm{C}$.

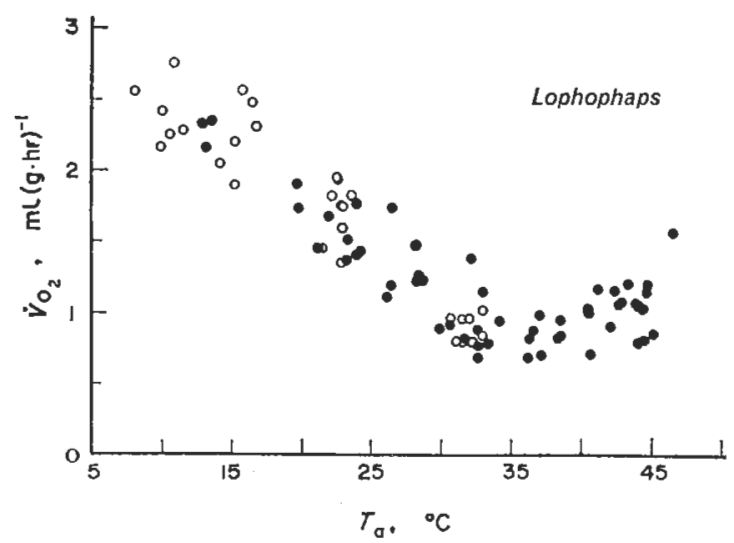

Fig. 2. Relation of nocturnal metabolic rate $\left(\dot{V}_{\mathrm{O}_{2}}\right)$ to ambient temperature $\left(T_{\mathrm{a}}\right)$ for postabsorptive western plumed pigeons resting in the dark. Shaded circles: Feb.-Mar. (austral summer) determinations. Unshaded circles: May (austral fall) determinations. 


\section{Oxygen consumption}

As noted above, the zone of thermal neutrality for Feb.-Mar. birds extends from $33^{\circ} \mathrm{C}$ to approximately $39^{\circ} \mathrm{C}$ (Fig. 2). The mean rate of oxygen consumption in this zone, $0.88 \pm 0.17$ (S.D.) $\mathrm{ml}(\mathrm{g} \mathrm{hr})^{-1}$, has been taken as the standard metabolic rate (SMR). The mean value for May birds tested at $30-33^{\circ} \mathrm{C}$ is $0.87 \pm 0 \cdot 10 \mathrm{ml}$ $(\mathrm{g} \mathrm{hr})^{-1}$. While this figure does not differ significantly from the mean value for Feb.-Mar. birds, it should not be regarded as the SMR in the absence of data on May individuals for $T_{\mathrm{a}}$ 's exceeding $33^{\circ} \mathrm{C}$.

Metabolic rates of both summer (Feb.-Mar.) and fall (May) western plumed pigeons rise sharply with decreasing $T_{\mathrm{a}}$ below $30-33^{\circ} \mathrm{C}$ (Fig. 2). With $\dot{V}_{\mathrm{o}}$ expressed in $\mathrm{ml}(\mathrm{g} \mathrm{hr})^{-1}$ and $T_{\mathrm{a}}$ in ${ }^{\circ} \mathrm{C}$, the least squares lines for the two sets of data are described by the following linear equations:

$\begin{array}{lll}\text { Feb.-Mar. } & \dot{V}_{\mathrm{O}_{\mathrm{a}}}=3 \cdot 20-0.072 T_{\mathrm{a}}, & S_{\mathrm{b}}= \pm 0.007 \\ \text { May } & \dot{V}_{\mathrm{O}_{\mathrm{a}}}=3 \cdot 00-0.055 T_{\mathrm{a}}, & S_{\mathrm{b}}= \pm 0.010 .\end{array}$

Analysis of covariance indicates that these equations do not differ significantly $(P>0 \cdot 05)$. This suggests that the difference in thermal regimes under which the animals existed in captivity in summer and fall did not produce any shift in thermal acclimation involving response to moderate and cool conditions.

Metabolic rates of western plumed pigeons measured in Feb.-Mar. at $T_{\mathrm{a}}$ 's above thermal neutrality generally exceeded the SMR by only a small amount (Fig. 2). The modest extent of the rise in $\dot{V}_{\mathrm{O}_{\mathrm{a}}}$ with $T_{\mathrm{a}}$ above $39^{\circ} \mathrm{C}$ is of interest because of the conspicuous gular flutter displayed by these birds during exposure to hot conditions (see below).

\section{Evaporative water loss}

Rates of evaporative water loss by western plumed pigeons at absolute humidities between 3 and $10 \mathrm{~mm} \mathrm{Hg}$ are plotted against $T_{\mathrm{a}}$ in Fig. 3. These rates do not change appreciably between the lowest temperatures tested and $33-35^{\circ} \mathrm{C}$ in either Feb.-Mar. or May birds. The values obtained for these groups in this range of temperature do not differ significantly. Evaporative water loss rises sharply with $T_{\mathrm{a}}$ above $35^{\circ} \mathrm{C}$ (Feb.-Mar. birds), and the maximum $\dot{m}_{\text {we }}$ observed, $22.4 \mathrm{mg}$ $(\mathrm{g} \mathrm{hr})^{-1}$, is approximately fifteen times the level prevailing at moderate and cool $T_{\mathrm{a}}$ 's. The evaporative water losses of May birds were not measured at $T_{\mathrm{a}}$ 's exceeding $33^{\circ} \mathrm{C}$.

\section{Gular futtering}

Under hot conditions, western plumed pigeons commenced intermittent gular fluttering when their $T_{\mathrm{b}}$ 's reached $41 \cdot 3-43 \cdot 3^{\circ} \mathrm{C}$, depending on the individual. Continuous fluttering first developed between 42.0 and $43.7^{\circ} \mathrm{C}$. Frequency of this flutter ranged from 565 to 750 cycles/min, varying both within and between individuals (Fig. 4). This range covers values reported for mourning doves (Zenaidura macroura) by Bartholomew et al. (1968) and domestic pigeons by 
Calder \& Schmidt-Nielsen (1967). As in these other species, the frequency of gular fluttering in western plumed pigeons is not strongly correlated with $T_{\mathrm{b}}$.

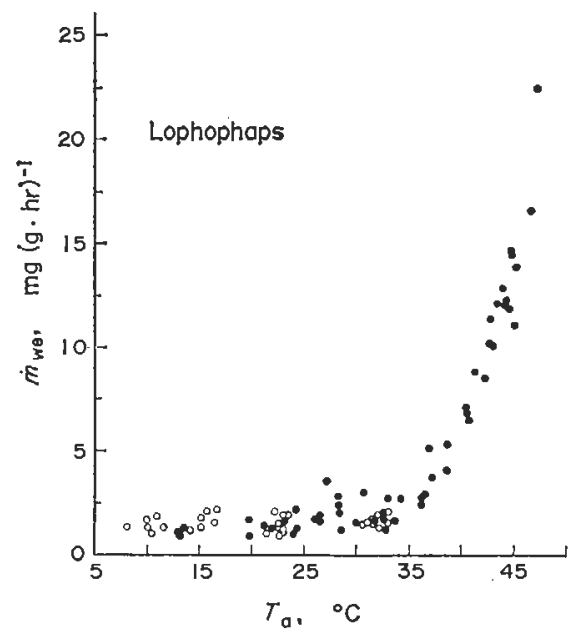

FIG. 3. Relation of nocturnal rate of evaporative water loss $\left(\dot{m}_{\mathrm{we}}\right)$ to ambient temperature $\left(T_{\mathrm{a}}\right)$ for postabsorptive western plumed pigeons resting in the dark at absolute humidities of 3-10 $\mathrm{mm} \mathrm{Hg}$ (aqueous vapor pressure). Measurements were made simultaneously with those on metabolism (Fig. 2). Shaded circles: Feb.-Mar. (austral summer) determinations. Unshaded circles: May (austral fall) determinations.

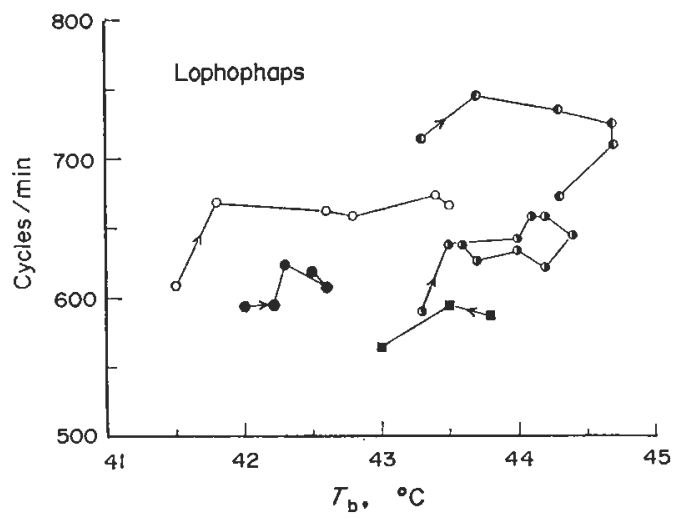

Fig. 4. Frequency of gular flutter in several western plumed pigeons at various body temperatures $\left(T_{\mathrm{b}}\right)$. Observations made at ambient temperatures $c a .44-47^{\circ} \mathrm{C}$. The lines connect points in temporal sequence. The arrows point away from the initial value determined for each bird. Each type of symbol represents a different bird. 


\section{DISCUSSION}

\section{Thermal conductance}

The availability of simultaneously measured values for $T_{\mathrm{b}}, \vec{V}_{\mathrm{o}}$, and $\dot{m}_{\text {we }}$ from our tests of temperature responses by western plumed pigeons allows determination of thermal conductances for these birds. In these determinations the heat dissipated evaporatively has been subtracted from total heat production. Thus the values presented (Fig. 5) represent so-called dry conductance (see King \& Farner, 1964; Calder \& Schmidt-Nielsen, 1967). Thermal conductance of western plumed

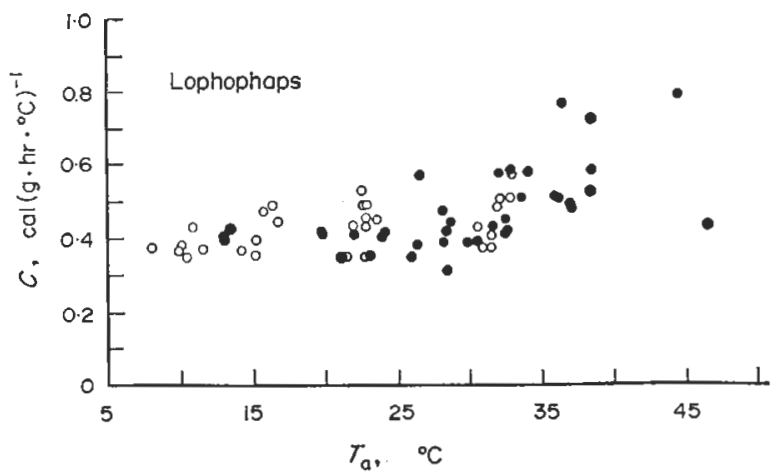

FIG. 5. Relation of thermal conductance, $C$, to ambient temperature $\left(T_{\mathrm{a}}\right)$ in western plumed pigeons $\left(C=[M-E] /\left[T_{\mathrm{b}}-T_{\mathrm{a}}\right]\right.$, where $M$ and $E$ represent weightspecific rates of heat production and evaporative heat dissipation, respectively, and $T_{\mathrm{b}}$ represents body temperature. Based on data presented in Figs. 1-3; conversion of metabolism and evaporative water loss to calories was accomplished using the following relations, $4.8 \mathrm{cal} / \mathrm{ml} \mathrm{O}_{2}$ and $0.58 \mathrm{cal} / \mathrm{mg} \mathrm{H}_{2} \mathrm{O}$. Shaded circles : Feb.-Mar. (austral summer) determinations. Unshaded circles: May (austral fall) determinations.

pigeons rises with increasing $T_{\mathrm{a}}$ 's above $32-33^{\circ} \mathrm{C}$ and the level at $39^{\circ} \mathrm{C}$, the upper limit of thermal neutrality, is about 1.5 times the minimal level. The scatter of values between 40 and $47^{\circ} \mathrm{C}$ probably results from the disproportionately large effect exerted by small errors in temperature determinations in this range, where the differential between $T_{\mathrm{b}}$ and $T_{\mathrm{a}}$ is narrow. Thermal conductance remains stable at the minimal level of $0.4 \mathrm{cal}\left(\mathrm{g} \mathrm{hr}{ }^{\circ} \mathrm{C}\right)^{-1}$ from 32 to $33^{\circ} \mathrm{C}$ to the lowest $T_{\mathrm{a}}$ 's employed in this study. No differences in this regard were noted between Feb.-Mar. and May birds. The weight-relative figure cited for minimal conductance corresponds to a surface-relative value of $1.8 \mathrm{kcal}\left(\mathrm{m}^{2} \mathrm{hr}{ }^{\circ} \mathrm{C}\right)^{-1}$, surface areas of western plumed pigeons having been calculated with Meeh's formula. This is within the range of estimates $\left(1 \cdot 5-2.5 \mathrm{kcal} \mathrm{m}^{-2} \mathrm{hr}^{-1}{ }^{\circ} \mathrm{C}^{-1}\right)$ obtained in metabolic studies for several other species of birds weighing 75-90 g (Dawson W. R. \& Hudson, 1970; Drent \& Stonehouse, 1971). 


\section{Relation of evaporative water loss and metabolism}

The ratio of evaporative water loss to oxygen consumption of western plumed pigeons is relevant to the consideration of the net impact of such loss upon the water economy of these xerophilous birds. The temperature dependence of this ratio for birds tested at absolute humidities between 3 and $10 \mathrm{~mm} \mathrm{Hg}$ is illustrated in Fig. 6. The values of most interest are those occurring below the lower critical temperature, the point at which $\dot{V}_{\mathrm{O}_{\mathrm{a}}}$ rises with decreasing $T_{\mathrm{a}}$ while $\dot{m}_{\text {we }}$ remains

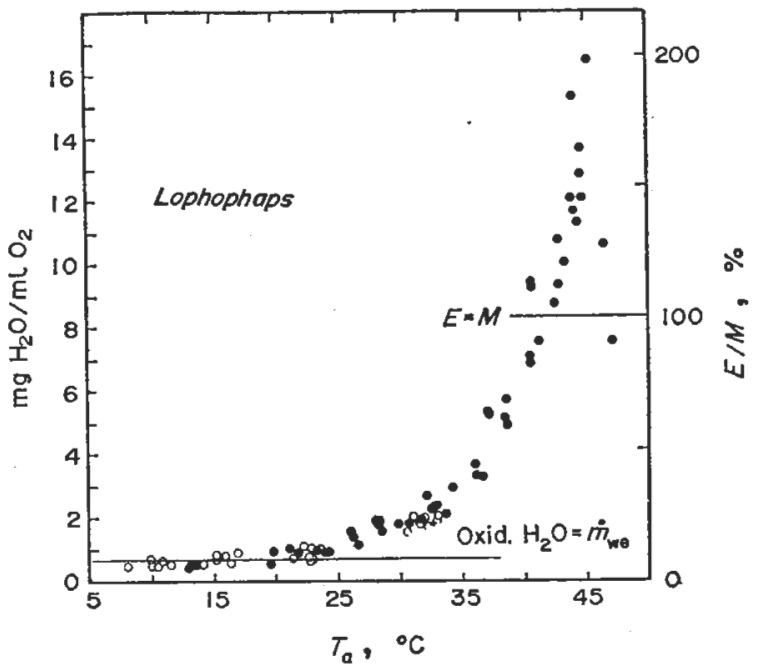

Frg. 6. Ratios of evaporative water loss to oxygen consumption (in $\mathrm{mg} \mathrm{H}_{2} \mathrm{O} / \mathrm{ml}$ $\mathrm{O}_{2}$ ) at various ambient temperatures $\left(T_{\mathrm{a}}\right)$ and absolute humidities of $3-10 \mathrm{~mm}$ $\mathrm{Hg}$ (aqueous vapor pressure) for western plumed pigeons (based on the data presented in Figs. 2 and 3). The lower horizontal line marks the maximum ratio (left-hand ordinate) at which oxidative production of water would offset loss of this fluid through evaporation. The right-hand ordinate expresses the ratios between evaporative water loss and metabolism in terms of the percentage of metabolic heat dissipated evaporatively (see legend for Fig. 5 for equivalents used to convert data to caloric terms). The upper horizontal line marks the level (right-hand ordinate) at which calories dissipated evaporatively match calories produced. Shaded circles: Feb.-Mar. (austral summer) determinations. Unshaded circles: May (austral fall) determinations.

stable or declines slightly. The relative stability of evaporative water loss below thermal neutrality, despite a probable increase in ventilation rate, presumably results at least in part from the expiration of cooler air with lower carrying capacity for water vapor at cooler $T_{\mathrm{a}}$ 's (Schmidt-Nielsen et al., 1970). The ratios of evaporative water loss to oxygen consumption for $T_{\mathrm{a}}$ 's below $30^{\circ} \mathrm{C}$ are all less than $2.0 \mathrm{mg} \mathrm{H}_{2} \mathrm{O} / \mathrm{ml} \mathrm{O}_{2}$ and thirteen are at or below $0.67 \mathrm{mg} / \mathrm{ml}$, the level at which maximal production of oxidative water would match the evaporative output (see Table 1 in Schmidt-Nielsen \& Schmidt-Nielsen, 1952). These thirteen values suggest that a favorable relation conld exist between evaporative water loss and 
oxidative water production of western plumed pigeons in moderate and cool environments. This might be of value during winter when rainfall is scanty or lacking (Nuttonson, 1958) and temperatures are relatively cool in arid tropical regions where these animals occur. Evaporative cooling during hot summer days must tend to deplete the water resources of western plumed pigeons, for water is lost in this process at several times the rate prevailing at moderate and cool $T_{\mathrm{a}}$ 's (Fig. 3) and very little of this loss is offset by the oxidative production of this fluid (Fig. 6). The utilization of surface water noted by Gould (1865) and others thus appears to constitute a critical facet of the adjustment of western plumed pigeons to their environment.

Conversion of the simultaneous values of $\dot{V}_{\mathrm{O}}$, and $\dot{m}_{\mathrm{we}}$ to calories permits assessment of the role of evaporative cooling in the heat economy of western plumed pigeons at various $T_{\mathrm{a}}$ 's (Fig. 6). The capacity for such cooling is of particular importance owing to the intense heat encountered by these birds over a major part of the year. Marble Bar, Western Australia, which lies in the range of the western plumed pigeon, is recognized as one of the warmest places on earth (Nuttonson, 1958), having as many as 160 consecutive days on which maximum shade temperatures reached or exceeded $38^{\circ} \mathrm{C}\left(100^{\circ} \mathrm{F}\right)$. Evaporation accounts for less than 20 per cent of heat production in western plumed pigeons tested below $33^{\circ} \mathrm{C}$. Above this $T_{\mathrm{a}}$, the proportion rises sharply as the differential between $T_{\mathrm{b}}$ and $T_{\mathrm{a}}$ narrows and finally becomes reversed (Figs. 1 and 6). Evaporative cooling accounts for 85 and 140 per cent of heat production by western plumed pigeons at 40 and $44^{\circ} \mathrm{C}$, respectively. Values for other birds tested under comparable conditions of absolute humidity (5-8 $\mathrm{mm} \mathrm{Hg}$ vapor pressure) at $40^{\circ} \mathrm{C}$ range from 36 to 99 per cent (Dawson W. R. \& Hudson, 1970). At $44-45^{\circ} \mathrm{C}$ the percentages extend from 94 to 180 per cent (Lasiewski et al., 1966a; Dawson W. R. \& Hudson, 1970; Lasiewski et al., 1970). Previous estimates of evaporative cooling capacity of greatest potential interest pertain to other pigeons. However, direct comparisons are hindered by the lack of standardized humidity conditions. The domestic pigeon can dissipate 120 per cent of its heat production at $45^{\circ} \mathrm{C}$ and a water vapor pressure of $35 \mathrm{~mm} \mathrm{Hg}$ (Calder \& Schmidt-Nielsen, 1967). The figures at $44^{\circ} \mathrm{C}$ for the xerophilous Inca dove (Scardafella inca) are 107 per cent at $23 \mathrm{~mm} \mathrm{Hg}$ vapor pressure (MacMillen \& Trost, 1967a) and 120 per cent at 9-15 mm Hg (Lasiewski \& Seymour, 1972).

The maximum rate of evaporative cooling observed in our western plumed pigeons was equivalent to 193 per cent of the rate of heat production (Fig. 6). This value is considerably higher than the figures reported for most other birds, except for goatsuckers and frogmouths (Bartholomew et al., 1962; Dawson W. R. \& Fisher, 1969; Lasiewski, 1969; Lasiewski et al., 1970). The relatively high values evident in these birds all seem to reflect relatively low metabolic levels (see below regarding metabolic level of western plumed pigeons) as well as excellent capacities for effecting evaporation.

As noted previously, the augmentation of evaporative water loss in western plumed pigeons entailed no pronounced rise in metabolic rate (Figs. 2 and 3 ). 
Indeed, the excess of $\dot{V}_{0}$ at $44-47^{\circ} \mathrm{C}$ over SMR appears in most cases largely accounted for by the Van't Hoff effect, if our calculations based on the extent of hyperthermia developing above thermal neutrality (Fig. 1) and the assumption of a $Q_{10}$ of 2.0 for $\dot{V}_{\mathrm{o}_{\mathrm{z}}}$ are correct. Even without these calculations, the augmentation of evaporative water loss by the western plumed pigeon seems metabolically inexpensive (Fig. 2). Perhaps this results from a reliance on resonant panting of the type shown by Crawford \& Kampe (1971) in the domestic pigeon, as well as gular fluttering. Since this latter activity is probably synchronized with thoracoabdominal movements of polypneic western plumed pigeons, the relatively narrow band of frequencies evident in the gular fluttering of individual birds (Fig. 4) might be an indication of resonant panting. Lest these considerations be overemphasized, it should also be pointed out that recent studies of passerines, birds that do not employ resonant panting or gular fluttering, also indicate a rather low metabolic cost for effecting respiratory evaporative cooling (Rising, 1969; Lustick, 1970; Lasiewski \& Seymour, 1972).

\section{Physiological characteristics of western plumed pigeons advantageous for a desert} existence

Field observations (Dawson, unpublished) and results of this laboratory study indicate that western plumed pigeons possess a number of physiological and behavioral traits that are particularly advantageous in contending with heat and aridity. Evaporative water loss at moderate and cool temperatures can largely be offset by production of oxidative water. The general level of metabolism in this pigeon is only 71 per cent of the value predicted for a bird of its size from the equation of Aschoff \& Pohl (1970) relating metabolism and weight in non-passerine birds during the inactive phase of their daily cycle. Such a relatively low level of SMR should be advantageous in several ways. It minimizes food requirements in an environment of low productivity. It fosters a relatively low rate of evaporative water loss, as indicated by the fact that the rate of evaporative water loss of western plumed pigeons at $25^{\circ} \mathrm{C}$ is only two-thirds of the value predicted for non-passerines from the equation of Crawford \& Lasiewski (1968), $\dot{m}_{\text {we }}=0.351 W^{0.61}$, where $\dot{m}_{\text {we }}$ is in $\mathrm{g} \mathrm{H}_{2} \mathrm{O} /$ day and $W$ is body weight in $\mathrm{g}$. Finally, the relatively low metabolic rate of this pigeon results in a correspondingly low caloric burden in hot environments. While this still necessitates the expenditure of considerable water in evaporative cooling, the amount is undoubtedly less than a more conventional level of metabolism would require under similar conditions. Like other birds, western plumed pigeons store some heat when in hot environments. The resultant hyperthermia serves to restrict further gain of heat and to facilitate thermolysis by passive heat transfer in the manner described by Dawson W. R. \& Bartholomew (1968). Western plumed pigeons are subjected to severe heat during summer in their natural habitat. Under such circumstances their effortless and highly effective evaporative cooling, which involves gular fluttering, is undoubtedly of considerable value. The periodic visits of pigeons to water holes allow the replenishment of the fluid expended in evaporative cooling. Utilization of surface 
water for drinking has also been shown to be important for pigeons inhabiting arid portions of North America (Bartholomew \& Dawson, 1954; MacMillen \& Trost, 1966, 1967a).

\section{Levels of SMR in columbid birds}

The unexpectedly low SMR of the western plumed pigeon prompted a review of information on columbid birds to determine if pigeons generally have low metabolic rates or if metabolic level in this group might correlate with habitat. This information is summarized in Table 1. It all pertains to birds resting in a postabsorptive state at night. Considerable heterogenity in metabolic level is evident among the species for which data are available. The three birds (Columba livia, Streptopelia risoria and $S$. decaocto) from non-desert situations have values ranging from 93 to 117 per cent of predicted values. Among the other species included in Table 1, an inverse correlation exists between the relative level of SMR and the extent to which their distributions are restricted to arid situations. The mourning dove, a species ranging widely over North America in desert as well as humid regions, has an SMR that is 6-7 per cent above the rates estimated with the Aschoff-Pohl equation and 7-8 per cent above those estimated with the equation we have obtained from data on representatives of the genera Columba and Streptopelia (see Table 1). These deviations from predicted values in the mourning dove are not out of line with the scatter evident in the actual data pertaining to these other genera (Table 1). The crested pigeon (Ocyphaps lophotes), a bird found in dry agricultural areas as well as desert regions throughout Australia, has an SMR corresponding to 81 per cent of values predicted from the two equations utilized in Table 1 . The Inca dove ( $S$. inca), a species residing in the deserts of southwestern United States, and the arid lowlands of Mexico and Central America, also shows a relatively low level of SMR, the observed value corresponding to 79 and 83 per cent of those predicted from the Aschoff-Pohl equation and the relation developed for the two genera of pigeons (Table 1). The western plumed pigeon is entirely confined to rocky desert areas in northwestern Australia and its SMR is the lowest of any among the values presented, constituting 71 and 73 per cent of rates predicted from the equations used here (Table 1).

Relatively low levels of SMR are not without precedent among birds and mammals. For example, Australian marsupials have been shown to have rates that are only about two-thirds those of eutherian mammals of comparable size (Dawson T. J. \& Hulbert, 1970; Dawson W. R. \& Bennett, 1971). Among rodents, a number of species have been shown to have relatively low SMR's (McNab \& Morrison, 1963; McNab, 1966a; MacMillen \& Lee, 1970; Wang \& Hudson, 1970). A similar situation has been detected in a hyrax (Hyrax brucei) by Bartholomew \& Rainy (1971). Among birds, the fact that non-passerine birds tend to have lower SMR's than passerine species (Lasiewski \& Dawson, 1967) is now well known. Among non-passerines, some intraordinal variation is evident (see Zar, 1968). Thus owls (Ligon, 1968) and caprimulgiform birds, goatsuckers and frogmouths are characterized by particularly low SMR's (Bartholomew et al., 1962; Lasiewski \& 
Table 1-Standard metabolic Rates (SMR'S) of PIgeons

\begin{tabular}{|c|c|c|c|c|c|c|}
\hline \multirow[b]{2}{*}{ Species } & \multirow{2}{*}{$\begin{array}{c}\text { Body } \\
\text { wt. } \\
\text { (g) }\end{array}$} & \multirow[b]{2}{*}{$\begin{array}{c}T_{\mathrm{b}} \\
\left({ }^{\circ} \mathrm{C}\right)\end{array}$} & \multirow[b]{2}{*}{$\begin{array}{c}\mathrm{SMR} \\
\left(\mathrm{ml} \mathrm{O} \mathrm{g}^{-1} \mathrm{hr}^{-1}\right)\end{array}$} & \multicolumn{2}{|c|}{ Observed SMR/predicted SMR (\%) } & \multirow[b]{2}{*}{ Reference } \\
\hline & & & & $\begin{array}{l}\text { Non-passerine } \\
\text { SMR }=100 \%\end{array}$ & $\begin{array}{c}\text { Pigeont } \\
\mathrm{SMR}=100 \%\end{array}$ & \\
\hline \multirow[t]{7}{*}{ C. livia (domestic pigeon) } & 263 & 41 & 0.85 & 93 & - & Riddle et al. (1932a) \\
\hline & 266 & - & $1 \cdot 10$ & 98 & - & Gelineo (1955) \\
\hline & 300 & - & 0.83 & 94 & - & Benedict \& Riddle (1929) \\
\hline & 311 & $40 \cdot 3$ & 0.92 & 106 & - & Burckard et al. (1933) \\
\hline & 315 & $39 \cdot 7$ & 0.99 & 115 & - & $\begin{array}{l}\text { Calder \& Schmidt-Nielsen } \\
\text { (1967) }\end{array}$ \\
\hline & 372 & - & $0 \cdot 83$ & 101 & - & Herzog $(1930)$ \\
\hline & 525 & - & 0.78 & 104 & - & Benedict \& Riddle (1929) \\
\hline \multirow[t]{3}{*}{ S. risoria (ringdove) } & 141 & - & 0.99 & 99 & - & Riddle et al. (1933) \\
\hline & 150 & - & $1 \cdot 04$ & 114 & 一 & Benedict \& Riddle (1929) \\
\hline & 150 & $41 \cdot 7$ & 0.98 & 98 & - & Riddle et al. (1930) \\
\hline \multirow[t]{3}{*}{ S. decaocta (collared dove) } & 152 & - & $1 \cdot 23$ & 117 & - & Giaja \& Males (1928) \\
\hline & 155 & - & $1 \cdot 02$ & 98 & - & Gelineo (1955) \\
\hline & \multicolumn{5}{|c|}{ Xerophilous pigeons } & \\
\hline \multirow[t]{2}{*}{ Z. macroura (mourning dove) } & 91 & $40 \cdot 9$ & $1 \cdot 27$ & 106 & 108 & Hudson \& Brush (1964) \\
\hline & 123 & - & $1 \cdot 17$ & 107 & 107 & Riddle et al. (1932b) \\
\hline S. inca (Inca dove) $\ddagger$ & 42 & $40 \cdot 2$ & $1 \cdot 16$ & 79 & 83 & $\begin{array}{l}\text { MacMillen \& Trost } \\
\text { (1967a) }\end{array}$ \\
\hline
\end{tabular}




\section{L. ferruginea (western plumed} pigeon)

* SMR predicted with an equation based on the relation between metabolism and body weight established by Aschoff \& Pohl (1970) for non-passerine birds in the inactive phase of their daily cycle: $\dot{V}_{\mathrm{O}_{2}}=4 \cdot 01 W^{-0 \cdot 266}$, where $V_{\mathrm{O}_{2}}$ and $W$ are in $\mathrm{ml}\left(\mathrm{g} \mathrm{hr}\right.$ ) ${ }^{-1}$ and $\mathrm{g}$, respectively.

$\uparrow$ SMR predicted from an equation obtained for the data on representatives of Columba and Streptopelia by the method of least squares: $\dot{V}_{\mathrm{O}_{\mathrm{a}}}=3 \cdot 13 W^{-0.217}$, where $\grave{V}_{\mathrm{O}_{\mathrm{a}}}$ and $W$ are expressed in $\mathrm{ml}(\mathrm{g} \mathrm{hr})^{-1}$ and $\mathrm{g}$, respectively.

† Lasiewski \& Seymour (1972) also present metabolic values for this species. These are slightly higher than the ones cited here, but pertain to only four birds. 
Dawson, 1964; Dawson W. R. \& Fisher, 1969; Lasiewski, 1969; Lasiewski et al., 1970). However, such rates are also found among some representatives of other groups, e.g. colies (Bartholomew \& Trost, 1970). Many of these species are inhabitants of arid regions, but it is not clear whether their relatively low SMR's reflect specific adjustments to the environment or simply membership in taxonomic groups characterized by low metabolism. Thus it has generally not been possible to test, in any rigorous way, Scholander et al.'s (1950) assertion that SMR for wild animals is fundamentally determined by body size and does not reflect climatic conditions.

Pigeons comprise a group with a wide environmental range extending from equatorial to high temperate latitudes and xeric to mesic habitats. The correlation we have detected between SMR and extent of restriction to arid environments in this group suggests that the adjustment of pigeons to desert regions has involved reduction of SMR. In the case of the western plumed pigeon, at least, this modification does not appear to be the result of acclimation, since metabolic rates of birds during the hot summer and cool fall in our study did not differ significantly. We interpret the data reviewed here on columbid metabolism as indicating that SMR can indeed be correlated with climate, contrary to the view of Scholander et al. (1950). The advantages of a low SMR for existence in a hot arid environment have been described previously (see above; Dawson W. R. \& Bennett, 1971).

The mechanism responsible for the relatively low SMR's of certain xerophilous pigeons is at present unclear. However, it is possible to rule out certain factors that have been suggested to be responsible for the deviation of metabolic level from general relationships for mammals. A low level of body temperature has been implicated in the relatively low SMR's obtained from Australian marsupials and monotremes (Schmidt-Nielsen et al., 1966; Dawson T. J. \& Hulbert, 1970). The discrepancy between the rates of these animals and those of eutherian mammals thus can be explained in terms of the Van't Hoff effect. In contrast, $T_{\mathrm{b}}$ 's recorded during metabolic measurements of xerophilous pigeons are at the level observed for species from non-desert environments (Table 1). A claim has been made that the relatively low weight-specific metabolic rates of certain rodents are due to a disproportionately high fat content, purported to have low metabolic activity (Hayward, 1965a, b). McNab (1966b) has refuted this view. Although we do not have precise estimates of the adiposity of our western plumed pigeons, none of our birds appeared especially fat. Judgment of this was facilitated by the localized and superficial character of fat deposits in land birds, particularly in the throat region. In any event, the metabolic rate observed for our western plumed pigeons would require gross adiposity and this was not evident. We suspect that the relatively low SMR of the western plumed pigeon and of other xerophilous columbids will ultimately be explained in terms of reduced activity of mitochondrial enzymes, reduced concentrations of these enzymes, or increased $\mathrm{P} / \mathrm{O}$ ratios. The birds included in Table 1 would appear to constitute an excellent series in which to approach the problem of metabolic level from a biochemical standpoint. 


\section{SUMMARY}

1. Body temperatures of western plumed pigeons averaged approximately $39^{\circ} \mathrm{C}$ at the conclusion of nocturnal metabolic experiments conducted at ambient temperatures below $30^{\circ} \mathrm{C}$. Above $30^{\circ} \mathrm{C}$, body temperature varied directly with ambient temperature. Birds tested between 42 and $47^{\circ} \mathrm{C}$ generally remained $0 \cdot 5-3 \cdot 0^{\circ} \mathrm{C}$ cooler than their surroundings for at least $2 \mathrm{hr}$.

2. The zone of thermal neutrality for western plumed pigeons in summer extends from $33^{\circ} \mathrm{C}$ to approximately $39^{\circ} \mathrm{C}$. The mean standard metabolic rate is $0 \cdot 88 \pm 0 \cdot 17$ (S.D.) $\mathrm{ml} \mathrm{O}_{2}(\mathrm{~g} \mathrm{hr})^{-1}$. This is only 71 per cent of the value anticipated for non-passerine birds of comparable size $(81 \mathrm{~g})$. Below thermal neutrality, metabolism varies with ambient temperature in accordance with the following equations:

$$
\begin{array}{ll}
\dot{V}_{\mathrm{o}_{\mathrm{z}}}=3 \cdot 20-0 \cdot 072 T_{\mathrm{a}} & \text { (summer), } \\
\dot{V}_{\mathrm{o}_{\mathrm{a}}}=3 \cdot 00-0 \cdot 055 T_{\mathrm{a}} & \text { (fall), }
\end{array}
$$

where $\dot{V}_{\mathrm{o}_{2}}$ is oxygen consumption in $\mathrm{ml} \mathrm{O}_{2}(\mathrm{~g} \mathrm{hr})^{-1}$ and $T_{\mathrm{a}}$ is ambient temperature in ${ }^{\circ} \mathrm{C}$. The two equations do not differ significantly.

3. Western plumed pigeons have relatively low rates of evaporative water loss at cool and moderate ambient temperatures. The rate at $25^{\circ} \mathrm{C}$ is about two-thirds that expected for birds of comparable size. These pigeons can increase evaporative water loss as much as fifteen-fold between moderate and high ambient temperatures. Panting and gular fluttering contribute to this ability. The metabolic cost of these activities is very small.

4. The minimal level of dry thermal conductance did not vary in western plumed pigeons between summer and fall. The mean value, $1.8 \mathrm{kcal}\left(\mathrm{m}^{2} \mathrm{hr}{ }^{\circ} \mathrm{C}\right)^{-1}$, is in line with minimal figures reported for other birds of comparable size.

5. Key adjustments of western plumed pigeons to heat and aridity include their sharing in a general avian capacity for tolerating hyperthermia and their possessing a relatively low rate of standard metabolism, relatively low rates of evaporative water loss at cool and moderate ambient temperatures, effortless mechanisms for increasing respiratory evaporation and good capacities for evaporative cooling (the maximum ratio of evaporative cooling to heat production approximated $2 \cdot 0$ at high temperatures and a water vapor pressure of $7 \mathrm{~mm} \mathrm{Hg}$ ).

6. Review of metabolic information on members of the avian family Columbidae (pigeons) shows that the standard metabolic rates of species occurring in nondesert environments range from 93 to 117 per cent of levels anticipated for nonpasserine birds of comparable size. On the other hand, species closely associated with hot, arid situations have rates that are 71-81 per cent of predicted values. Relative level of standard metabolism thus appears correlated with climate in members of the family Columbidae.

Acknowledgements-This investigation was supported in part by grants to W. R. D. from the National Science Foundation (GB-3656, GB-25022), the Australian-American Educational Foundation and the Horace H. Rackham School of Graduate Studies, The University of Michigan. Support for A. F. B. was provided by a N.S.F. Graduate Fellowship. Mr. Bob Dear of the Western Australian Fisheries and Fauna Department collected the birds for 
our use and we greatly appreciate his assistance. We are also grateful to Professors $\mathrm{H}$. Waring and A. R. Main for numerous courtesies and use of the facilities of the Department of Zoology, University of Western Australia.

\section{REFERENCES}

Aschoff J. \& Pohl H. (1970) Rhythmic variations in energy metabolism. Fedn Proc. Fedn Am. Socs exp. Biol. 29, 1541-1552.

Bartholomew G. A. \& Dawson W. R. (1954) Body temperature and water requirements of the mourning dove, Zenaidura macroura marginella. Ecology 35, 181-187.

Bartholomew G. A., Hudson J. W. \& Howell T. R. (1962) Body temperature, oxygen consumption, evaporative water loss, and heart rate in the poor-will. Condor 64, 117-125.

Bartholomew G. A., Lasiewsik R. C. \& Crawford E. C., JR. (1968) Patterns of panting and gular flutter in cormorants, pelicans, owls, and doves. Condor 70, 31-34.

Bartholomew G. A. \& MacMilleN R. E. (1960) The water requirements of mourning doves and their use of sea water and $\mathrm{NaCl}$ solutions. Physiol. Zoöl. 33, 171-178.

Bartholomew G. A. \& Rainy M. (1971) Regulation of body temperature in the rock hyrax, Heterohyrax brucei. F. Mammal. 52, 81-95.

Bartholomew G. A. \& 'Trost C. H. (1970) Temperature regulation in the speckled mousebird, Colius striatus. Condor 72, 141-146.

Benedict F. G. \& Riddle O. (1929) Measurement of the basal heat production of pigeonsII. Physiological technique. F. Nutr, 1, 497-538.

Burckard E., DontchefF L. \& Kayser C. (1933) Le rythme nycthéméral chez le pigeon. Ann. Physiol. Physicochim. Biol. 9, 303-368.

Calder W. A. \& Schmidt-Nielsen K. (1966) Evaporative cooling and respiratory alkalosis in the pigeon. Proc. natn. Acad. Sci. U.S.A. 55, 750-756.

Calder W. A. \& Schmidt-Nielsen K. (1967) Temperature regulation and evaporation in the pigeon and the roadrunner. Am. F. Physiol, 213, 883-889.

Calder W. A. \& Schmidt-Nielsen K. (1968) Panting and blood carbon dioxide. Am. $\mathcal{F}$. Physiol. 215, 477-482.

Crawford E. C., Jr. \& Kampe G. (1971) Resonant panting in pigeons. Comp. Biochem. Physiol. 40A, 549-552.

Crawford E. C., JR. \& Lasiewski R. C. (1968) Oxygen consumption and respiratory evaporation of the emu and rhea. Condor 70, 333-339.

Dawson 'T. J. \& Hulbert A. J. (1970) Standard metabolism, body temperature, and surface areas of Australian marsupials. Am. F. Physiol. 218, 1233-1238.

Dawson W. R. \& Bartholomew G. A. (1968) Temperature regulation and water economy of desert birds. In Desert Biology (Edited by Brown G. W., Jr.), Vol. 1. Academic Press, New York.

Dawson W. R. \& BenneTt A. F. (1971) Thermoregulation in the marsupial Lagorchestes conspicillatus. F. Physiol., Paris 63, 239-241.

Dawson W. R. \& Fisher C. D. (1969) Responses to temperature by the spotted nightjar (Eurostopodus guttatus). Condor 71, 49-53.

Dawson W. R. \& Hudson J. W. (1970) Birds. In Comparative Physiology of Thermoregulation (Edited by WhitTow G. C.), Vol. 1. Academic Press, New York.

Depocas F. \& Hart J. S. (1957) Use of the Pauling oxygen analyzer for measurement of oxygen consumption of animals in open-circuit systems and in a short-lag, closed circuit apparatus. F. appl. Physiol. 10, 388-392.

Drent R. H. \& STONEHouse B. (1971) Thermoregulatory responses of the Peruvian penguin, Spheniscus humboldti. Comp. Biochem. Physiol. 40A, 689-710.

Gelineo S. (1955) Température d'adaptation et production de chaleur chez les oiseaux de petite taille. Arch. Sci. Physiol. 9, 225-243. 
Giaja J. \& Males B. (1928) Sur la valeur de métabolisme de base de quelques animaux en fonction de leur surface. Ann. Physiol. Physicochim. Biol. 4, 875-904.

Goodwin D. (1967) Pigeons and Doves of the World. Trustees of the British Museum (Natural History), London.

Gould J. (1865) Handbook to the Birds of Australia, Vol. II. Published by Author, London. Hayward J. S. (1965a) The gross body composition of six geographic races of Peromyscus. Can. F. Zool. 43, 297-308.

HaYWARD J. S. (1965b) Metabolic rate and its temperature-adaptive significance in six geographical races of Peromyscus. Can. F. Zool. 43, 309-323.

Herzog D. (1930) Untersuchungen über den Grundumsatz der Vogel. Wiss. Arch. Landwirtsch. Abt. B Tiernähr. Tierzucht 3, 610-626.

Hudson J. W. \& Brush A. H. (1964) A comparative study of the cardiac and metabolic performance of the dove, Zenaidura macroura, and the quail, Lophortyx californicus. Comp. Biochem. Physiol. 12, 157-170.

KING J. R. \& FARNer D. S. (1964) Terrestrial animals in humid heat: birds. In Handbook of Physiology, Sect. 4: Adaptation to the Environment (Edited by Dill D. B.). Am. Physiol. Soc., Washington, D.C.

LASIEWski R. C. (1969) Physiological responses to heat stress in the poorwill. Am. $\mathcal{F}$. Physiol. 217, 1504-1509.

Lasiewsik R. C., Acosta A. L. \& Bernstein M. H. (1966a) Evaporative water loss in birdsI. Characteristics of the open flow method of determination, and their relation to estimates of thermoregulatory ability. Comp. Biochem. Physiol. 19, 445-457.

Lasiewski R. C., Acosta A. L. \& Bernstein M. H. (1966b) Evaporative water loss in birds-II. A modified method for determination by direct weighing. Comp. Biochem. Physiol. 19, 459-470.

Lasiewsi R. C. \& Dawson W. R. (1964) Physiological responses to temperature in the common nighthawk. Condor 66, 477-490.

LASIEWSKI R. C. \& DAwson W. R. (1967) A re-examination of the relation between standard metabolic rate and body weight in birds. Condor 69, 13-23.

Lasiewsi R. C., Dawson W. R. \& Bartholomew G. A. (1970) Temperature regulation in the little Papuan frogmouth, Podargus ocellatus. Condor 72, 332-338.

LASIEWSKi R. C. \& SEYMOUR R. S. (1972) Thermoregulatory responses to heat stress in four species of birds weighing approximately 40 grams. Physiol. Zoöl. 45, 106-118.

Ligon J. D. (1968) Biology of the elf owl, Micrathene whitneyi. Misc. Publ. Mus. Zoology, Univ. of Michigan 136, 1-70.

LusTICK S. (1970) Energetics and water regulation in the cowbird (Molothrus ater obscurus). Physiol. Zoöl. 43, 270-287.

MACMiLLEN R. E. \& LEE A. K. (1970) Energy metabolism and pulmocutaneous water loss of Australian hopping mice. Comp. Biochem. Physiol. 35, 355-369.

Macmillen R. E. \& Trost C. H. (1966) Water economy and salt balance in white-winged and Inca doves. Auk 83, 441-456.

MacMillen R. E. \& Trost C. H. (1967a) Thermoregulation and water loss in the Inca dove. Comp. Biochem. Physiol. 20, 263-273.

MacMillen R. E. \& Trost C. H. (1967b) Nocturnal hypothermia in the Inca dove, Scardafella inca. Comp. Biochem. Physiol. 23, 243-253.

MCFARLAND D. \& Wright P. (1969) Water conservation by inhibition of food intake. Physiol. Behav. 4, 95-99.

MCNAB B. K. (1966a) The metabolism of fossorial rodents: a study of convergence. Ecology 47, 712-733.

MCNAB B. K. (1966b) 'The influence of fat deposits on the basal rate of metabolism in desert homeotherms. Comp. Biochem. Physiol. 26, 337-343.

MCNAB B. K. \& MorRison P. R. (1963) Body temperature and metabolism in subspecies of Peromyscus from arid and mesic environments. Ecol. Monogr. 33, 63-82. 
Nuttonson M. Y. (1958) The Physical Environment and Agriculture of Australia with Special Reference to its Winter Rainfall Regions. American Institute of Crop Ecology, Washington, D.C.

Riddle O., Christman G. \& Benedict F. G. (1930) Differential response of male and female ring doves to metabolism measurement at higher and lower temperatures. $A m . \mathcal{F}$. Physiol. 95, 111-120.

Riddle O., Nussmann T. C. \& Benedict F. G. (1932a) Metabolism during growth in a common pigeon. Am. F. Physiol. 101, 251-259.

Riddle O., Smith G. C. \& Benedict F. G. (1932b) Basal metabolism of the mourning dove and some of its hybrids. Am. F. Physiol. 101, 260-267.

Riddle O., Smith G. C. \& Benedict F. G. (1933) Studies on the physiology of reproduction in birds-XXXII. Basal metabolism and the temperature factor in brooding ring doves. Am. Э. Physiol. 105, 428.

Rising J. D. (1969) A comparison of metabolism and evaporative water loss of Baltimore and Bullock orioles. Comp. Biochem. Physiol. 31, 915-925.

Schmidt-Nielsen K., Dawson T. J. \& Crawford E. J., Jr. (1966) Temperature regulation in the echidna (Tachyglossus aculeatus). F. cell. Physiol. 67, 63-72.

Schmidt-Nielsen K., Hainsworth F. R. \& Murrish D. E. (1970) Counter-current exchange in the respiratory passages: effect on water and heat balance. Respir. Physiol. 9, 263-276.

Schmidt-Nielsen K. \& Schmidt-Nielsen B. (1952) Water metabolism of desert mammals. Physiol. Rev. 32, 135-166.

Scholander P. F., Hock R., Walters V. \& Irving L. (1950) Adaptation to cold in arctic and tropical mammals and birds in relation to body temperature, insulation, and basal metabolic rate. Biol. Bull. 99, 259-271.

SCOTHORNE R. J. (1959) On the response of the duck and the pigeon to intravenous hypertonic saline solutions. Q. $\mathscr{f l}$ exp. Physiol. 44, 200-207.

Serventy D. L. \& Whittell H. M. (1962) Birds of Western Australia. Paterson Brokensha Pty. Ltd., Perth, Western Australia.

SMY'TH M. \& Bartholomew G. A. (1966) Effects of water deprivation and sodium chloride on the blood and urine of the mourning dove. Auk 83, 597-602.

Wang L. C. \& Hudson J. W. (1970) Some physiological aspects of temperature regulation in the normothermic and torpid hispid pocket mouse, Perognathus hispidus. Comp. Biochem. Physiol. 32, 275-293.

WilloughBy E. J. (1966) Water requirements of the ground dove. Condor 68, 243-248. ZAR J. H. (1968) Standard metabolism comparisons between orders of birds. Condor 70, 278.

Key Word Index-Environmental adaptation; desert birds; Lophophaps ferruginea; pigeons; oxygen consumption; evaporative water loss; standard metabolic rate; gular fluttering; thermal conductance; body temperature; thermal regulation. 